\title{
The cognitive neuroscience of autism
}

\section{S Baron-Cohen}

\section{The psychology and biology of a complex developmental condition}

A utism is diagnosed when a child or adult has abnormalities in a "triad" of behavioural domains: social development, communication, and repetitive behaviour/obsessive interests. ${ }^{2}$ Autism can occur at any point on the IQ continuum, and IQ is a strong predictor of outcome. ${ }^{3}$ Autism is also invariably accompanied by language delay (no single words before 2 years old). Asperger syndrome (AS $)^{4}$ is a subgroup on the autistic spectrum. People with AS share many of the same features as are seen in autism, but with no history of language delay and with an IQ in the average range or above. In this editorial, the main cognitive theories of autism are summarised. These are then followed by a summary of the key neurobiological findings.

\section{AUTISM: COGNITIVE ASPECTS}

The mind blindness theory of autism ${ }^{5}$ proposed that in autism spectrum conditions there are deficits in the normal process of empathy, relative to mental age. These deficits can occur by degrees. The term "empathising" encompasses a range of other terms: "theory of mind", "mind reading", "empathy", and taking the "intentional stance". 6 Empathy involves two major elements: (1) the ability to attribute mental states to oneself and others, as a natural way to make sense of agents, ${ }^{7-9}$ and (2) having an emotional reaction that is appropriate to the other person's mental state (such as sympathy).

Since the first test of mind blindness in children with autism, ${ }^{10}$ there have been more than 30 experimental tests. The vast majority of these have revealed profound impairments in the development of their empathising ability. These are reviewed elsewhere. ${ }^{511}$ Some children and adults with AS only show their empathising deficits on age appropriate adult tests. ${ }^{12-14}$ This deficit in their empathising is thought to underlie the difficulties such children have in social and communicative development, ${ }^{15}{ }^{16}$ and in the imagination of others' minds. ${ }^{17}{ }^{18}$ We can think of these symptoms as the triad of deficits (see fig 1).

Systemising is the drive to analyse systems, in order to understand and predict the behaviour of inanimate events. Systems are all around us in our environment, and include technical systems (such as machines and tools); natural systems (such as biological and geographical phenomena); abstract systems (such as mathematics or computer programs). The way we make sense of any of these systems is in terms of underlying rules and regularities, or specifically an analysis of input-operation-output relations. ${ }^{19}$ The empathising-systemising (E-S) theory holds that alongside the empathising deficits in autism (see above), systemising is either intact or superior. ${ }^{20}$ Studies suggest systemising in autism is at least in line with mental age, or superior. ${ }^{21-25}$ Systemising may relate to a different set of features which we can think of as the triad of strengths (see fig 2).

People with autism spectrum conditions show unusually strong repetitive behaviour, a strong desire for routines, and a "need for sameness". One cognitive account of this aspect of the syndrome is the executive dysfunction theory. ${ }^{26-28}$ This assumes that autism involves a form of frontal lobe pathology leading to persevering or inability to shift attention. There is some evidence for such executive deficits. ${ }^{29}$ But the fact that it is possible for people with AS to exist who have no demonstrable executive dysfunction while still having deficits in empathising and talents in systemising, ${ }^{30}$ suggests that executive dysfunction is unlikely to be a core feature of autism spectrum conditions.

The executive account has also traditionally ignored the content of "repetitive behaviour". The E-S theory in contrast draws attention to the fact that much repetitive behaviour involves the child's "obsessional" or strong interests with mechanical systems (such as light switches or water faucets) or other systems that can be understood in terms of rules and regularities. Rather than these behaviours being a sign of executive dysfunction, these may reflect the child's intact or even superior interest in systems. One study suggests that autistic obsessions are not random with respect to content (which would be predicted by the content free executive to cluster in the domain of systems. ${ }^{31}$

Weak central coherence $(C C)^{32}{ }^{33}$ refers to the individual's preference for local detail over global processing. This has been demonstrated in terms of an autistic superiority on the embedded figures task (EFT) and the block design subtest. ${ }^{25} 3435$ It has also been shown in terms of an autistic deficit in integrating fragments of objects and integrating sentences within a paragraph. ${ }^{36}$ The faster and more accurate performance on the EFT and block design test have been interpreted as evidence of good segmentation skills, and superior attention to detail. The latter has also been demonstrated on visual search tasks. ${ }^{37} 38$

Systemising requires excellent attention to detail, identifying parameters that may then be tested for their role in the behaviour of the system under examination. So, both the E-S theory and the CC theory predict excellent attention to detail. However, the E-S and CC theories also make opposite predictions when it comes to an individual with autism being able to understand a whole system. The E-S theory predicts that a person with autism, faced with a new system to learn, will show a stronger drive to learn the system compared with someone without autism, so long as there are underlying rules and regularities that can be discovered. Moreover, they will readily grasp that a change of one parameter in one part of the system may have distant effects on another part of the system. In contrast, the CC theory predicts that they should fail to understand whole (global) systems or the relation between parts of a system. This has not yet been tested.

\section{AUTISM: NEUROBIOLOGICAL ASPECTS Neuroanatomy and neuropathology}

Anatomical abnormalities have been identified in many brain areas in autism. These include the cerebellum, ${ }^{39-42}$ the brain stem, ${ }^{42} 43$ frontal lobes, ${ }^{44-47}$ parietal lobes, ${ }^{48}$ hippocampus, ${ }^{49}{ }^{50}$ and the amygdale. ${ }^{49}$ Epilepsy also occurs commonly, at least in classic autism. ${ }^{51}$ In terms of neuropathology, the number of Purkinje cells in the cerebellar cortex is abnormally low. ${ }^{52-55}$ This has been postulated to lead to disinhibition of the cerebellar deep nuclei and consequent overexcitement of the thalamus and cerebral cortex. ${ }^{56}$ Abnormalities in the

Abbreviations: AS, Asperger syndrome; CC, central coherence; EFT, embedded figures task; E-S, empathising-systemising; HFA, high functioning autism; MRI, magnetic resonance imaging. 
Triad of deficits

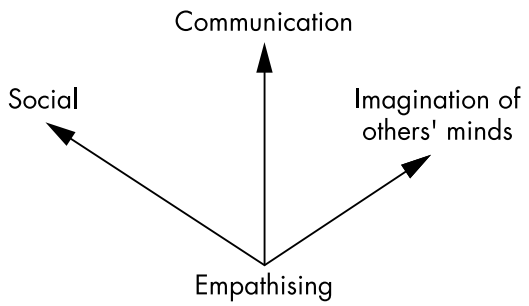

Figure 1 The triad of impairments in autism

density of packing of neurons in the hippocampus, amygdala, and other parts of the limbic system have also been reported..$^{54} 55$ An abnormally low degree of dendritic branching was also found in a Golgi analysis of the hippocampus of two autistic brains, ${ }^{57}$ though it remains to be seen if such an abnormality is confirmed in a larger sample. A separate report suggests a reduction in the size of cortical minicolumns and an increase in cell dispersion within these minicolumns. These might indicate an increase in the number of and connectivity between minicolumns. ${ }^{58} 59$

\section{Neurophysiology}

Hyper arousal in response to sensory input, and decreased ability to select between competing sensory inputs, has been reported..$^{60}$ Functional neuroimaging suggests increased activity in sensory areas of the brain normally associated with stimulus driven processing, and decreased activity in areas normally associated with higher cognitive processing. Thus, on the EFT, people with autism show unusually high activation in ventral occipital areas and abnormally low activation in prefrontal and parietal areas. ${ }^{62}$ In one study they also failed to show normal activity in the fusiform "face area", ${ }^{63}$ instead showing abnormally high activity in the peristriate cortex and inferior temporal gyrus. ${ }^{64}{ }^{65}$ The visual N2 to novel stimuli is also heightened to irrelevant stimuli. ${ }^{66}$ The $\mathrm{P} 3$ in response to auditory stimuli is abnormally generalised to occipital sites in visual cortex. ${ }^{67}$

Regarding EEG results, the Pl evoked potential is either abnormally heightened in response to stimuli that are the target of attention, or abnormally generalised to stimuli that are outside the target of attention. ${ }^{68}$ Both hemispheres show abnormal activationindiscriminately-during shifts of attention into either hemifield. ${ }^{69}{ }^{70}$ Regarding attention research, a deficit has been found in rapid shifting of attention between modalities, ${ }^{39}$ between spatial locations $^{69}$ 71-76 and between object features. ${ }^{77} 78$
Triad of strengths

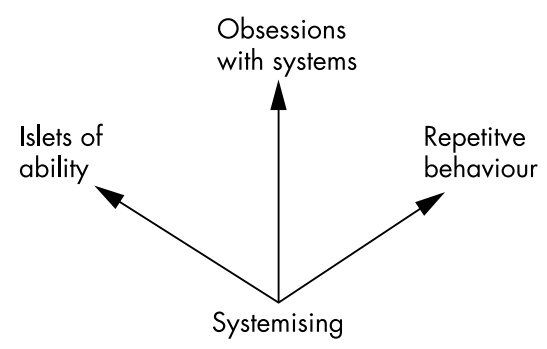

Figure 2 The triad of strengths in autism

\section{Morphometry}

Magnetic resonance imaging (MRI) morphometry shows volume deficits in the cerebellum, ${ }^{40-42}{ }^{79}$ the brainstem, ${ }^{42}$ and posterior corpus callosum. ${ }^{80}$ Regarding the cerebellar abnormalities, a subgroup shows increased cerebellar volume. ${ }^{81}$ A volume deficit has also been reported in the parietal lobe. ${ }^{48}$ Neuropsychology suggests this is associated with a narrowed spatial focus of attention. ${ }^{68}$

\section{Longitudinal morphometry}

Using either MRI volumetric analysis, or measures of head circumference, the autistic brain appears to involve transient postnatal macroencephaly. ${ }^{82}$ Neonates later diagnosed with autism or PDD-NOS (Pervasive Developmental Disorder-Not Otherwise Specified) have normal head circumference, but by $2-4$ years of age $90 \%$ of these have MRI based brain volumes larger than average. ${ }^{44-47}$ This reflects an enlargement of cerebellar and cerebral white matter, and cerebral grey matter. ${ }^{45} 83$ Enlargement of superficial white matter tracts containing cortico-cortical fibres may persist abnormally late into development, while the internal capsule and corpus callosum are smaller. ${ }^{84}$ Cerebellar and cerebral white matter volumes, and cerebellar vermis size can distinguish $95 \%$ of toddlers with autism from normal controls, and predict if the child with autism will be high or low functioning. ${ }^{45}$ The overgrowth is anterior to posterior (frontal lobes being the largest). This increase in volume of cortical grey matter may reflect a failure of synaptic pruning, or an excess of synaptogenesis. ${ }^{56}$

\section{The "social brain"}

A neural basis of empathy has built on a model first proposed by Brothers. ${ }^{85}$ She suggested-from animal lesion studies $^{86}$ single cell recording studies, ${ }^{87}$ and neurological studies-that social intelligence was a function of three regions: the amygdala, the orbitofrontal and medial frontal cortex, and the superior temporal sulcus and gyrus
(STG). Together, she called these the "social brain". Abnormalities in autism have been found in the amygdala, the orbito and the medial frontal cortex.

Regarding the amygdala, there are four lines of evidence for an amygdala deficit in autism. ${ }^{88}$ Firstly, a neuroanatomical study of autism at postmortem found microscopic pathology (in the form of increased cell density) in the amygdala, in the presence of normal amygdala volume. ${ }^{89}{ }^{90}$ Secondly, patients with autism tend to show a similar pattern of deficits to those seen in patients with amygdala lesions. ${ }^{91}$ Thirdly, a recent structural MRI study of autism reported reduced amygdala volume. ${ }^{92}$ Finally, in a recent functional magnetic resonance imaging (fMRI) study, adults with high functioning autism (HFA) or Asperger syndrome (AS) showed significantly less amygdala activation during a mentalising task (Reading the Mind in the Eyes task) compared with normal. ${ }^{93}$

Reduced activity has also been found in the left medial frontal cortex, ${ }^{94}$ during an empathising (theory of mind) task, and also in the orbitofrontal cortex. ${ }^{95}$

\section{GENETICS OF AUTISM SPECTRUM CONDITIONS}

Ultimately, the cognitive and neural abnormalities in autism spectrum conditions are likely to be caused by genetic factors. The sibling risk rate for autism is approximately $4.5 \%$, or a tenfold increase over general population rates. ${ }^{96}$ In an epidemiological study of same sex autistic twins, it was found that $60 \%$ of monozygotic (MZ) pairs were concordant for autism versus no dizygotic, (DZ) pairs. ${ }^{97}$ When they considered a broader phenotype (of related cognitive or social abnormalities), $92 \%$ of $\mathrm{MZ}$ pairs were concordant versus $10 \%$ of DZ pairs. The high concordance in $\mathrm{MZ}$ twins indicated a high degree of genetic influence, and the risk to a co-MZ twin can be estimated at over 200 times the general population rate.

Molecular genetic studies are beginning to narrow down candidate regions. There is still little consensus, but two regions have been identified in several (but not all) studies. These are 15q1113, near the $\mathrm{GABA}_{A} \beta_{3}$ receptor subunit gene $\left(\mathrm{GABRB}_{3}\right)$ and a second one on 17q11.2, near the serotonin transporter gene (SLC6A4). The latter is of interest because of reports of increased serotonin $(5 \mathrm{HT})$ levels of platelets in autism [204]. Serotonin innervates the limbic system, and so plausibly plays a role in emotion recognition and empathy. Mothers homozygous for $\mathrm{GABRB}_{3}$ knockout fail to engage in normal nurturing behaviour and have epileptiform EEG. ${ }^{98}{ }^{99}$ At least four loci on the $\mathrm{X}$ 
chromosome have also been implicated in autism, and are of interest for their power to explain the sex ratio in autism (markedly biased towards males). These are the neuroligin genes (NLGN3, NLGN4), FMRl (which causes fragile $X$ syndrome), and MECP2. Several reviews of the genetics of autism literature are available, but this is a fast changing field..$^{100-102}$

As of yet, specific genes for autism have not yet been identified, despite the encouraging possibility of candidate regions on chromosomes. The future of research in this field will be not only to isolate the relevant genes but also to understand the function of these genes, and ultimately the relation between these different causal levels in autism. It is hoped that during this research endeavour there will also be evaluations of the most promising treatments.

\section{ACKNOWLEDGEMENTS}

The author was supported by the MRC during the period of this work. I am grateful to Matthew Belmonte for discussions of the neuroscience of autism literature. This editorial has benefited from a preview of Belmonte et al (in press).

J Neurol Neurosurg Psychiatry

2004;75:945-948.

doi: $10.1136 /$ /nnp. 2003.018713

Correspondence to: S Baron-Cohen, Autism Research Centre, Departments of Experimental Psychology and Psychiatry, University of Cambridge, Douglas House, Cambridge CB2 2AH, UK; sb205@cam.ac.uk

\section{REFERENCES}

1 APA. DSM-IV Diagnostic and Statistical Manual of Mental Disorders. 4th edn. Washington DC: American Psychiatric Association, 1994.

2 ICD-10. International classification of diseases. 10th edn. Geneva, Switzerland: World Health Organisation, 1994.

3 Rutter M. Language disorder and infantile autism. In: Rutter M, Schopler E, eds. Autism: a reappraisal of concepts and treatment. New York: Plenum, 1978.

4 Asperger H. Die "Autistischen Psychopathen" im Kindesalter. Archiv fur Psychiatrie und Nervenkrankheiten 1944;117:76-136.

5 Baron-Cohen S. Mindblindness: an essay on autism and theory of mind. Boston: MIT Press/ Bradford Books, 1995

6 Dennett D. The intentional stance. Cambridge, Mass: MIT Press/Bradford Books, 1987.

7 Baron-Cohen S. How to build a baby that can read minds: Cognitive mechanisms in mindreading. Cahiers de Psychologie Cognitive/Current Psychology of Cognition 1994; 13:513-52.

8 Leslie A. ToMM, ToBy, and Agency: core architecture and domain specificity. In Hirschfeld L, Gelman S, eds. Domain specificity in cognition and culture. New York: Cambridge University Press, 1995.

9 Premack D. The infant's theory of self-propelled objects. Cognition 1990;36:1-16.

10 Baron-Cohen S, Leslie AM, Frith U. Does the autistic child have a 'theory of mind'? Cognition 1985;21:37-46.

11 Baron-Cohen S, Tager-Flusberg H, Cohen D, eds. Understanding other minds: perspectives from autism. Oxford University Press, 1993.

12 Baron-Cohen, Joliffe T, Mortimore T, et al. Another advanced test of theory of mind: evidence from very high functioning adults with autism or Asperger Syndrome. J Child Psychol Psychiatry 1997;38:813-22.

13 Baron-Cohen $\mathbf{S}$, Wheelwright $\mathrm{S}$, Jolliffe $\mathrm{T}$. Is there a "language of the eyes"? Evidence from normal adults and adults with autism or Asperger syndrome. Visual Cognition 1997:4:311-31.

14 Baron-Cohen S, Wheelwright S, Hill J, et al. The 'Reading the Mind in the eyes' test revised version: A study with normal adults, and adults with Asperger Syndrome or High-Functioning autism. J Child Psychol Psychiatry 2001;42:241-52.

15 Baron-Cohen S. Social and pragmatic deficits in autism: cognitive or affective? J Autism Dev Disord 1988; 18:379-402.

16 Tager-Flusberg $\mathrm{H}$. What language reveals about the understanding of minds in children with autism. In: Baron-Cohen S, Tager-Flusberg $\mathrm{H}$, Cohen DJ, eds. Understanding other minds: perspectives from autism. Oxford: Oxford University Press, 1993.

17 Baron-Cohen S. Autism and symbolic play. British Journal of Developmental Psychology 1987:5:139-48.

18 Leslie AM. Pretence and representation: the origins of "theory of mind". Psychological Review 1987;94:412-26.

19 Baron-Cohen S. The extreme male brain theory of autism. Trends Cogn Sci 2002;6:248-54.

20 Baron-Cohen S, Wheelwright S, Griffin R, et al. The exact mind: empathising and systemising in autism spectrum conditions. In: Goswami U, ed. Handbook of cognitive development. Oxford: Blackwells, 2002

21 Baron-Cohen S, Wheelwright S, Scahill V, et al. Are intuitive physics and intuitive psychology independent? Journal of Developmental and Learning Disorders 2001;5:47-78.

22 Baron-Cohen S, Richler J, Bisarya D, et al. The Systemising Quotient (SQ): An investigation of adults with Asperger Syndrome or High Functioning Autism and normal sex differences. Philos Trans $R$ Soc Lond B Biol Sci 2003;358:361-74.

23 Baron-Cohen S, Leslie AM, Frith U. Mechanical, behavioural and intentional understanding of picture stories in autistic children. British Journal of Developmental Psychology 1986:4:113-25.

24 Lawson J, Baron-Cohen S, Wheelwright S. Empathising and systemising in adults with and without Asperger Syndrome. J Autism Dev Disord 2004 (in press).

25 Jolliffe T, Baron-Cohen S. Are people with autism or Asperger's Syndrome faster than normal on the Embedded Figures Task? J Child Psychol Psychiatry 1997;38:527-34.

26 Ozonoff S, Rogers S, Farnham J, et al. Can standard measures identify subclinical markers of autism? J Autism Dev Disord 1994;23:429-41.

27 Pennington B, Rogers S, Bennetto L, et al. Validity test of the executive dysfunction hypothesis of autism. In: Russell J, ed. Executive functioning in autism. Oxford: Oxford University Press, 1997.

28 Russell J. How executive disorders can bring about an inadequate theory of mind. In: Russell J ed. Autism as an executive disorder. Oxford: Oxford University Press, 1997.

29 Russell J, ed. Autism as an executive disorder. Oxford: Oxford University Press, 1997.

30 Baron-Cohen S, Wheelwright S, Stone V, et al. A mathematician, a physicist, and a computer scientist with Asperger Syndrome: performance on folk psychology and folk physics test Neurocase 1999:5:475-83.

31 Baron-Cohen S, Wheelwright S. Obsessions in children with autism or Asperger Syndrome: a content analysis in terms of core domains of cognition. Br J Psychiatry 1999:175:484-90.

32 Frith U. Autism: explaining the enigma. Oxford: Basil Blackwell, 1989.

33 Happe F. Studying weak central coherence at low levels: children with autism do not succumb to visual illusions. A research note. J Child Psychol Psychiatry 1996;37:873-7.

34 Shah A, Frith U. An islet of ability in autism: a research note. J Child Psychol Psychiatry 1983;24:613-20.
35 Shah A, Frith U. Why do autistic individuals show superior performance on the block design test? J Child Psychol Psychiatry 1993;34:1351-64.

36 Jolliffe T, Baron-Cohen S. Linguistic processing in high-functioning adults with autism or Asperger syndrome: Can global coherence be achieved? A further test of central coherence theory. Psychol Med 2000;30:1169-87.

37 Plaisted K, O'Riordan M, Baron-Cohen S. Enhanced discrimination of novel, highly similar stimuli by adults with autism during a perceptual learning task. J Child Psychol Psychiatry 1998:39:765-75.

38 Plaisted K, O'Riordan M, Baron-Cohen S. Enhanced visual search for a conjunctive target in autism: A research note. J Child Psychol Psychiatry 1998;39:777-83.

39 Courchesne E, Townsend J, Akshoomof NA, et al. Impairment in shifting attention in autistic and cerebellar patients. Behav Neurosci 1994; 108:848-65.

40 Murakami J, Courchesne E, Press G, et al. Reduced cerebellar hemisphere size and its relationship to vermal hypoplasia in autism. Arch Neurol 1989;46:689-94.

41 Courchesne E, Townsend J, Saitoh O. The brain in infantile autism: posterior fossa structures are abnormal. Neurology 1994;44:214-23.

42 Hashimoto T, Tayama M, Murakawa K, et al. Development of the brainstem and cerebellum in autistic patients. J Autism Dev Disord 1995:25:1-17.

43 Rodier PM, Ingram JL, Tisdale B, et al. Embryological origin for autism: developmental anomalies of the cranial nerve motor nuclei. J Comp Neurol 1996:370:247-61.

44 Carper RA, Courchesne E. Inverse correlation between frontal lobe and cerebellum sizes in children with autism. Brain 2000;123:836-44.

45 Courchesne E, Karns CM, Davis HR, et al. Unusual brain growth patterns in early life of patients with autistic disorder. Neurology 2001;57:245-54

46 Sparks BF, Friedman SD, Shaw DW, et al. Brain structural abnormalities in young children with autism spectrum disorder. Neurology 2002;59:184-92

47 Aylward EH, Minshew NJ, Field K, et al. Effects of age on brain volume and head circumference in autism. Neurology 2002;59:175-83.

48 Courchesne E, Press GA, Yeung-Courchesne R. Parietal lobe abnormalities detected with MR in patients with infantile autism. AJR Am J Roentgenol 1993;160:387-93.

49 Aylward EH, Minshew NJ, Goldstein G, et al. MRI volumes of amygdala and hippocampus in non-mentally retarded autistic adolescents and adults. Neurology 1999:53:2145.

50 Saitoh O, Karns CM, Courchesne E. Development of hippocampal formation from 2 to 42 years. Brain 2001;124:1317-24.

51 Ballaban-Gil K, Tuchman R. Epilepsy and epileptiform EEG: association with autism and language disorders. Ment Retard Dev Disabil Res Rev 2000;6:300-308

52 Williams RS, Hauser SL, Purpura DP, et al. Autism and mental retardation: neuropathologic studies performed in four retarded persons with autistic behaviour. Arch Neurol 1980;37:749-53.

53 Ritvo ER, Freeman BJ, Scheibel AB, et al. Lower Purkinje cell counts in the cerebella of four autistic subjects: initial findings of the UCLA NSAC autopsy research report. Am J Psychiatry 1986; 143:862-66.

54 Bauman M, Kempner T. Histoanatomic observation of the brain in early infantile autism. Neurology 1985;35:866-74

55 Bauman ML, Kemper TL. Neuroanatomic observations of the brain in autism. In: Bauman ML, Kemper TL, eds. The neurobiology of autism. Baltimore: John Hopkins University Press, 1994:119-45.

56 Belmonte MK, et al. Autism as a disorder of neural information processing: directions for research and targets for therapy. Molecular Psychiatry 2004 (in press)

57 Raymond G, Bauman M, Kemper T. Hippocampus in autism: a Golgi analysis. Acta Neuropathol 1996:91:117-19. 
58 Casanova MF, Buxhoeveden DP, Switala AE, et al. Minicolumnar pathology in autism. Neurology 2002;58:428-32.

59 Casanova MF, Buxhoeveden DP, Switala AE et al. Asperger's Syndrome and cortical neuropathology. J Child Neurol 2002;17:142-5

60 Tordjman S, Anderson GM, McBride PA, et al. Plasma beta-endorphin, adrenocorticotropin hormone and cortisol in autism. J Child Psychol Psychiatry 1997;38:705-15.

61 Hirstein W, Iversen P, Ramachandran VS Autonomic responses of autistic children to people and objects. Proc R Soc Lond B Biol Sci 2001;268: 1883-8.

62 Ring H, Baron-Cohen S, Williams S, et al. Cerebral correlates of preserved cognitive skills in autism. A functional MRI study of Embedded Figures task performance. Brain 1999; 122:1305-15

63 Pierce K, Muller R-A, Ambrose J, et al. Face processing occurs outside the fusiform 'face area' in autism; evidence from functional MRI. Brain 2001;124:2059-73.

64 Critchley HD, Daly EM, Bullmore ET, et al. The functional neuroanatomy of social behaviour. Brain 2000;123:2203-12.

65 Schultz R, Gauthier I, Klin A, et al. Abnormal ventral temporal cortical activity among individuals with autism and Asperger syndrome during face discrimination. Arch Gen Psychiatry 2000;57:331-40.

66 Kemner C, Verbaten MN, Cuperus JM, et al Visual and somotosensory event-related brain potentials in autistic children and three different control groups. Electroencephalogr Clin Neurophysiol 1994:92:225-37.

67 Kemner C, Verbaten MN, Cuperus JM, et al. Auditory event-related brain potentials in autistic children and three different control groups. Biol Psychiatry 1995:38:150-65.

68 Townsend J, Courchesne E. Parietal damage and narrow "spotlight" spatial attention. J Cogn Neurosci 1994;6:220-32.

69 Belmonte MK. Abnormal attention in autism shown by steady-state visual evoked potentials. Autism 2000;4:269-85.

70 Belmonte MK, Yurgelun-Todd DA. Functional anatomy of impaired selective attention and compensatory processing in autism. Cognitive Brain Research 2003;17:651-64.

71 Wainwright-Sharp JA, Bryson SE. Visual orienting deficits in high-functioning people with autism. J Autism Dev Disord 1993;23:1-13.

72 Wainwright-Sharp JA, Bryson SE. Visual-spatial orienting in autism. J Autism Dev Disord 1996;26:423-38.

73 Townsend J, Courchesne E, Egaas B. Slowed orienting of covert visual-spatial attention in autism: specific deficits associated with cerebellar and parietal abnormality. Development and Psychopathology 1996;8:563-84.

74 Townsend J, Singer-Harris N, Courchesne E. Visual attention abnormalities in autism: delayed orienting to locationi. J International Neuropsychol Soc 1996;2:541-50.

75 Townsend J, Courchesne E, Covington J, et al Spatial attention deficits in patients with acquired or developmental cerebellar abnormality. J Neurosci 1999;19:5632-43.

76 Harris NS, Courchesne E, Townsend J, et al. Neuroanatomic contributions to slowed orienting of attention in children with autism. Brain Res Cogn Brain Res 1999;8:61-71.

77 Courchesne E, Townsend J, Akshoomoff NA, et al. A new finding: impairment in shifting attention in autistic and cerebellar patients. In: Broman SH, Grafman J, eds. Atypical cognitive deficits in developmental disorders: implications for brain function. Hillsdale, New Jersey: Lawrence Erlbaum, 1994

78 Rinehart NJ, Bradshaw JL, Moss SA, et al. A deficit in shifting attention present in highfunctioning autism but not Asperger's disorder. Autism 2001;5:67-80.

79 Courchesne E, Yeung-Courchesne R, Press G, et al. Hypoplasia of cerebellar vermal lobules $\mathrm{VI}$ and VII in infantile autism. N Engl J Med 1988;318:1349-54.

80 Egaas B, Courchesne E, Saitoh O. Reduced size of corpus callosum in autism. Arch Neurol 1995:52:794-801.

81 Courchesne E, Saitoh O, Yeung-Courchesne R, et al. Abnormality of cerebellar vermian lobules $\mathrm{VI}$ and $\mathrm{VII}$ in patients with infantile autism: Identification of hypoplastic and hyperplastic subgroups with MR imaging. Am J Radio 1994; 162:123-30.

82 Courchesne E. Abnormal early brain development in autism. Molecular Psychiatry 2002:7:21-3.

83 Herbert MR, Zeigler DA, Deutsch CK, et al. Dissociations of cerebral cortex, subcortical and cerebral white matter volumes in autistic boys. Brain 2003; 126:1182-92.

84 Herbert MR, Zeigler DA, Makris N, et al. White matter increases in autism are largely in superficial radiate regions. International Meeting for Autism Research, Orlando, Florida, 2002.

85 Brothers L. The social brain: a project for integrating primate behaviour and neurophysiology in a new domain. Concepts in Neuroscience 1990;1:27-51.

86 Kling A, Brothers L. The amygdala and social behavior. In: Aggleton J, ed. Neurobiological

\section{Expanding clinical dimensions of essential tremor}

\section{J Findley}

\section{The non-motor manifestations of essential tremor may be important}

7 he paper in this issue by Chatterjee et al (page 958) ${ }^{1}$ is the first large cross sectional study of personality in people with essential tremor compared with a control group. This careful study showed higher scores in the essential tremor group on the transdimensional

personality questionnaire (TPQ) in the domain of harm avoidance-implying a personality with increased levels of pessimism, fearfulness, shyness, and anxiety, and easy fatigability.

Essential tremor is the commonest movement disorder seen in clinical aspects of emotion, memory, and mental dysfunction. New York: Wiley-Liss, Inc 1992.

87 Brothers L, Ring B, Kling A. Responses of neurons in the macaque amygdala to complex social stimuli. Behav Brain Res 1990;41:199-213.

88 Baron-Cohen S, Ring H, Bullmore $\mathrm{E}$, et al. The amygdala theory of autism. Neurosci Biobehav Rev 2000;24:355-64.

89 Bauman M, Kemper T. The neurobiology of autism. Baltimore: Johns Hopkins, 1994

90 Rapin I, Katzman R. Neurobiology of autism. Ann Neurol 1998:43:7-14.

91 Adolphs R, Sears L, Piven J. Abnormal processing of social information from faces in autism. J Cogn Neurosci 2001;13:232-40.

92 Abell F, Krams M, Ashburner J, et al. The neuranatomy of autism: a voxel-based whole brain analysis of structural scans. Cogn Neurosci 1999; 10:1647-51.

93 Baron-Cohen S, Ring $\mathrm{H}$, Wheelwright $\mathrm{S}$, et al Social intelligence in the normal and autistic brain: an FMRI study. Eur J Neurosci 1999; 11:1891-8.

94 Happe F, Ehlers S, Fletcher P, et al. Theory of mind in the brain. Evidence from a PET scan study of Asperger Syndrome. Neuro Report 1996;8:197-201

95 Baron-Cohen S, Ring H, Moriarty J, et al. Recognition of mental state terms: a clinical study of autism, and a functional neuroimaging study of normal adults. Br J Psychiatry 1994; 165:640-9

96 Jorde L, Hasstedt S, Ritvo E, et al. Complex segregation analysis of autism. Am J Hum Gen 1991;49:932-8.

97 Bailey A, Le Couteur A, Gottesman I, et al. Autism as a strongly genetic disorder: evidence from a British twin study. Psychol Med 1995;25:63-77.

98 Homanics GE, DeLorey TM, Firestone LL, et al. Mice devoid of gamma-aminobutyrate type $A$ receptor $\beta 3$ subunit have epilepsy, cleft palate and hypersensitive behaviour. Proc Nat Acad Sci U S A 1997;94:4143-8.

99 Delorey TM, Handforth A, Anagnostaras SG, et al. Mice lacking the $\beta 3$ subunit of the GABAa receptor have the epilepsy phenotype and many of the behavioural characteristics of Angelman syndrome. J Neurosci 1998;18:8505-14.

100 Cook Jnr EH. Genetics of autism. Child Adolesc Psychiatr Clin N Am 2001;10:333-50.

101 Folstein SE, Rosen-Sheidley B. Genetics of autism: complex aetiology for a heterogeneous disorder. Nat Rev Genet 2001;2:943-55.

102 Lauritsen $M$, Ewald $\mathrm{H}$. The genetics of autism. Acta Psychiatr Scand 2001;103:41 1-27.

practice and has hitherto been considered a pure motor disorder without evidence of neuronal degeneration or widespread changes in the central nervous system. The age specific prevalence is reported to be between $1 \%$ and 3\% of the general population. It is often given the prefix "benign," which is unfortunate as many affected individuals have physical, social, and psychological handicaps, and some are totally disabled. ${ }^{2}$

As with essential tremor, the early descriptions of other less common movement disorders, such as Parkinson's disease, did not mention or emphasise the non-motor manifestations, though these are now recognised to be an integral part of Parkinson's disease. However, in one of the earliest large studies of essential tremor, Minor described higher intelligence, fecundity, and longevity in the essential tremor 
group. ${ }^{3}$ Considering the overlap and commonality in phenomenology between essential tremor and Parkinson's disease, ${ }^{4}$ it is perhaps not surprising that in recent years non-motor manifestations have been increasingly recognised as an integral part of essential tremor.

The limited studies thus far have described abnormalities of cognition, affect, and personality in essential tremor. The cognitive impairments include deficits in verbal fluency, naming, recent memory, working memory, and mental set shifting. ${ }^{5}$ Higher levels of depression, anxiety, and obsessivecompulsive disorder are described in comparison with control groups. Interestingly, above average performances in the essential tremor compared with controls have been reported in the areas of general verbal and intellectual abilities, ${ }^{5}$ and this would be in line with the early observation of Minor. ${ }^{3}$ The severity of the cognitive deficits ranges from unnoticeable to severe. The largest impairments have been described in verbal fluency and mental set shifting. In some studies cognitive impairment and depression were of sufficient severity to interfere with activities of daily living. In some individuals the personality changes were significant enough to cause disturbance of psychosocial functioning or to provoke comment from family members. In general, patients with Parkinson's disease have more widespread and severe impairments.

When considering changes in the psychology, mood, and results of tests of cognition in essential tremor, consideration has to be given to the direct, or indirect, effects of the tremor itself. In none of the studies so far has any significant correlation been found between tremor severity and any measure of psychological or cognitive change. However, I am not convinced that sufficient numbers of patients with very severe essential tremor have yet been examined. Such cases may represent a separable subgroup-for example, some show clear evidence of cerebellar deficits. ${ }^{6}$ The concept that severe essential tremor represents a separable category was expounded eloquently by the late David Marsden.

Further longitudinal prospective comparative studies will be required to unravel the link between the tremor of essential tremor and the underlying mechanisms producing cognitive, personality, and psychological change. From the complexity of the non-motor manifestations and knowledge on the generation of essential tremor, it would seem unlikely that the phenomena can be linked to a change in a single neurotransmitter system. Non-motor manifestations of essential tremor-including changes in mood and personality and the disparate cognitive abnormalitiescould be subserved by abnormalities in frontal/subcortical pathways. ${ }^{5}$ However, the constellation of cognitive and affective changes resembles those described in the "cerebellar cognitive affective syndrome," which is found in cerebellar syndromes. ${ }^{7}$ Although the pathogenesis of essential tremor is still not understood, there is overwhelming evidence of involvement of the cerebellum, and current concepts and studies have shown that the cerebellum is functionally connected to the frontal cerebral cortex through feed forward and feed backward pathways. ${ }^{7}$ The cerebellar cognitive affective syndrome is more pronounced in patients with acute cerebellar lesions and therefore the slow onset of essential tremor may account for the generally milder symptoms described in the studies of this condition.

Non-motor manifestations of essential tremor will have to be considered in the assessment of patients under consideration for invasive treatments, such as stereotactic surgery or insertion of a deep brain stimulator. Limited evidence thus far available would suggest such procedures do not produce any deleterious effects on cognition and may result in a significant reduction in anxiety and an improvement in the quality of life.

$J$ Neurol Neurosurg Psychiatry 2004;75:948-949.

doi: 10.1136/jnnp.2004.041293

Correspondence to: Professor L J Findley, Essex Neurosciences Unit, Oldchurch Hospital,

Romford, Essex RM7 OBE, UK

lifindley@uk-consultants.co.uk

Competing interests: none declared

\section{REFERENCES}

1 Chatteriee A, Jurewicz EC, Applegate LM, et al. Personality in essential tremor: further evidence of non-motor manifestations of the disease. J Neurol Neurosurg Neuropsychiatry 2004;75:958-61.

2 Bain $\mathbf{P}$, Findley $\amalg$, Thompson PD, et al. A study of hereditary essential tremor. Brain 1994; 117:805-24.

3 Minor L. Uber das erbliche zitern Zblges. Neurol Psychiatr 1925;99:586-633.

4 Findley L, Gresty MA, Halmagyi GM. Tremor, the cogwheel phenomenon and clonus in Parkinson's disease. I Neurol Neurosurg Psychiatry 1981;44:534-46.

5 Lombardi WJ, Woolston DJ, Roberts JW, et al. Cognitive deficits in patients with essential tremor. Neurology 2001;57:785-90.

6 Stolze H, Petersen G, Raethjen J, et al. The gait disorder of advanced essential tremor. Brain $2001 ; 124: 2278-86$.

7 Schmahmann JD, Sherman JC. The cerebellar cognitive affective syndrome. Brain $1998 ; 121: 561-79$

\section{Optimising multi-task performance: opportunities for motoric neurorehabilitation}

\section{A Hirsch}

\section{The stops walking while talking test; a dual task for motoric neurorehabilitation-further complexities of the test?}

n their study, Hyndman and Ashburn administered the stops walking while talking test (SWWT) to predict the occurrence of falls (see $p$ 994, this issue). ${ }^{1}$ Optimising multi-task cognitive and motor performance and targeting individuals who may benefit from therapeutic interventions to improve gait and reduce falls after stroke are important goals of neurorehabilitation. Dual task paradigms, such as walking while talking, can substantially alter motor and cognitive performance in younger and older adults with and without pathology. ${ }^{23}$ The authors' results are particularly interesting in the light of the possibilities of dual task therapies to prevent falls in persons with brain dysfunction. For example, one study showed that treatment with electromagnet fields improves dual task performance. ${ }^{4}$ Much time is spent during rehabilitation to improve a patient's functional gait parameters and few therapies are evidence-based. Evidence-based techniques in motoric neurorehabilitation of gait following stroke often include treadmill training with partial body weight support (TTPBWS). Dramatic improvements in gait can be observed during a single TTPBWS session where patients practice 
up to several thousand gait cycles on a motorised treadmill, while their bodyweight is partially supported by a parachute harness. This is thought to maximise motor practice time because the treadmill "forces" patients to ambulate in a safe environment with minimal fear of falling. Future studies should address the complementary nature of SWWT during TTPBWS, by assessing the precise effect of a cognitive task on gait in older adults. ${ }^{5}$ Rather than asking simple questions and measuring if patients respond by stopping or not stopping, future studies should examine elements of speech itself, such as speech rate, grammatical complexity, sentence length and structure, and their effects on gait patterns. Gait velocity should be controlled and this can be done with a treadmill. Then we may begin to ask if gait (and speech) patterns differ between stopper and non-stoppers. Optimally, the effects on gait should be studied in greater detail using three dimensional computerised gait analysis systems. Lower extremity leg strength and activity level should also be assessed. Most importantly, does dual task therapy transfer to functional gains in a real world environment? Answers to these questions may give further insights into the wondrous potential of the brain to recover from injury.

\section{J Neurol Neurosurg Psychiatry} 2004;75:949-950.

doi: 10.1136/jnnp.2004.039917

Correspondence to: Dr MA Hirsch, Department of Physical Medicine and Rehabilitation, Johns
Hopkins University, Baltmore, Massachusetts, USA; mhirsch@jhmi.edu

\section{REFERENCES}

1 Hyndman D, Ashburn AM. "Stops walking when talking" as a predictor of falls in people with stroke living in the community. J Neurol Neurosurg Psychiatry 2004;75:994-7.

2 Cocchini G, Della Sala S, Logie RH, et al. Dual task effects of walking when talking in Alzheimer's disease. Rev Neurol (Paris) 2004;160(1):74-80.

3 Kemper S, Herman RE, Lian CH. The costs of doing two things at once for young and older adults: talking while walking, finger tapping, and ignoring speech or noise. Psychol Aging 2003;18(2): 181-92.

4 Sandyk R. Treatment with electromagnetic fields improves dual-task performance (talking while walking) in multiple sclerosis. Int J Neurosci 1997:92(1-2):95-102.

5 Cran AJ, Skelton DA, Rosenberg ME, et al. The influence of a step-phase-triggered verbal cognitive task on (treadmill) walking (pilot study) [Abstract]. J Physio 2003;547:PC7.

\section{Clinical Evidence-Call for contributors}

Clinical Evidence is a regularly updated evidence based journal available worldwide both as a paper version and on the internet. Clinical Evidence needs to recruit a number of new contributors. Contributors are health care professionals or epidemiologists with experience in evidence based medicine and the ability to write in a concise and structured way.

Currently, we are interested in finding contributors with an interest in the following clinical areas:

Altitude sickness; Autism; Basal cell carcinoma; Breast feeding; Carbon monoxide poisoning; Cervical cancer; Cystic fibrosis; Ectopic pregnancy; Grief/bereavement; Halitosis; Hodgkins disease; Infectious mononucleosis (glandular fever); Kidney stones; Malignant melanoma (metastatic); Mesothelioma; Myeloma; Ovarian cyst; Pancreatitis (acute); Pancreatitis (chronic); Polymyalgia rheumatica; Post-partum haemorrhage; Pulmonary embolism; Recurrent miscarriage; Repetitive strain injury; Scoliosis; Seasonal affective disorder; Squint; Systemic lupus erythematosus; Testicular cancer; Varicocele; Viral meningitis; Vitiligo

However, we are always looking for others, so do not let this list discourage you.

\section{Being a contributor involves:}

- Appraising the results of literature searches (performed by our Information Specialists) to identify high quality evidence for inclusion in the journal.

- Writing to a highly structured template (about 2000-3000 words), using evidence from selected studies, within 6-8 weeks of receiving the literature search results.

- Working with Clinical Evidence Editors to ensure that the text meets rigorous epidemiological and style standards.

- Updating the text every eight months to incorporate new evidence.

- Expanding the topic to include new questions once every 12-18 months.

If you would like to become a contributor for Clinical Evidence or require more information about what this involves please send your contact details and a copy of your CV, clearly stating the clinical area you are interested in, to Claire Folkes (cfolkes@bmigroup.com).

\section{Call for peer reviewers}

Clinical Evidence also needs to recruit a number of new peer reviewers specifically with an interest in the clinical areas stated above, and also others related to general practice. Peer reviewers are health care professionals or epidemiologists with experience in evidence based medicine. As a peer reviewer you would be asked for your views on the clinical relevance, validity, and accessibility of specific topics within the journal, and their usefulness to the intended audience (international generalists and health care professionals, possibly with limited statistical knowledge). Topics are usually 2000-3000 words in length and we would ask you to review between $2-5$ topics per year. The peer review process takes place throughout the year, and our turnaround time for each review is ideally 10-14 days.

If you are interested in becoming a peer reviewer for Clinical Evidence, please complete the peer review questionnaire at www.clinicalevidence.com or contact Claire Folkes(cfolkes@bmigroup.com). 